\title{
Estimation of Monthly Actual Evapotranspiration Using NOAA-AVHRR Satellite Images
}

\section{NOAA-AVHRR 인공위성 영상을 이용한 월 실제증발산량 산정}

\author{
Kwon, Hyung Joong* ${ }^{*}$ Shin, Sha ChuI** $\cdot$ Kim, Seong Joon*** \\ 권 형 중-신 사 철-김 성 준
}

\begin{abstract}
The purpose of this study is to estimate monthly evapotranspiration (ET) using normalized difference vegetation index (NDVI) obtained from NOAA-AVHRR data sets. Actual evapotranspiration was evaluated by the complementary relationship, and monthly NDVI was obtained by maximum value composite method from daily NDVI images in the Korean peninsula for the year 2001. The monthly actual ETs for each land cover were compared with the monthly NDVIs to determine relationships between actual ET and NDVI for each land cover category. There was a high correlation between monthly NDVI and monthly mean actual ET. This study presents an alternative approach for land surface evapotranspiration based on remote sensing techniques.
\end{abstract}

Keywords : Evapotranspiration, Complementary relationship equation, NDVI, NOAA-AVHRR

\section{Introduction}

Evapotranspiration (ET) is the process by which water is evaporated from wet surfaces and transpired by plants (Chow, 1984). There are

* Graduate School, Konkuk University, Seoul, Korea

** Dept. of Civil Engineering, Andong Nat'l University, Andong, Korea

*** Dept. of Rural Engineering, Konkuk University, Seoul, Korea

Tel.: +82-2-450-3749

Fax: +82-2-444-0186

E-mail address: kimsj@konkuk.ac.kr many methods of estimating ET and potential ET such as soil-moisture sampling, lysimeter measurements, water balance, energy balance, groundwater fluctuations and ET equations, but it is very difficult to estimate ET by consideration of regional characteristics of topography or vegetation.

Most methods require various meteorological data and these equations are very complex. Also, these methods are not suitable for estimating of distributed ET. Factors controlling ET from ground are air temperature, humidity, wind, 
radiation, soil-moisture and so on. These factors strongly influence the vegetation, and the vegetation influences the ET directly. Therefore, there is a high correlation between the vegetation and the ET. To grasp vegetation condition at any area, NDVI calculated from NOAA-AVHRR data is utilized.

The relationship between vegetation and ET has been investigated by many researchers. Running and Nemani (1988) reported proportion between iNDVI (integrated NDVI) and yearly ET and Tada et al. (1994) estimated distributed ET using relationship between NDVI and ET and reported linear proportion between NDVI and ET. However, these studies have several assumption that relationship between NDVI and ET was fixed and adopted for all watershed. Therefore, there were not various relationships between NDVI and ET for various surface conditions.

The purpose of this study is to estimate monthly actual ET using high correlations between NDVI from NOAA-AVHRR data and ET which considered various watersheds and land cover conditions.

\section{Materials and Methods}

NOAA satellite was designed for making meteorological observation. This satellite have AVHRR sensor which have five channels from $0.58 \mu \mathrm{m}$ to $12.5 \mu \mathrm{m}$. Temporal resolution of this satellite is 16 cycles per day and spatial resolution of AVHRR images is $1.1 \mathrm{~km}$ by $1.1 \mathrm{~km}$. KMA (Korea Meteorological Administration) has received two scenes per day. In this study, AVHRR images for 2001 year were obtained from KMA.

Surface observations for meteorological condition are being conducted at the 77 manned stations with automated equipment. The sixteen elements including pressure, temperatures, humidity, precipitation, cloud coverage, winds, solar radiation and so on, are measured every three hours. Under special conditions, such as in

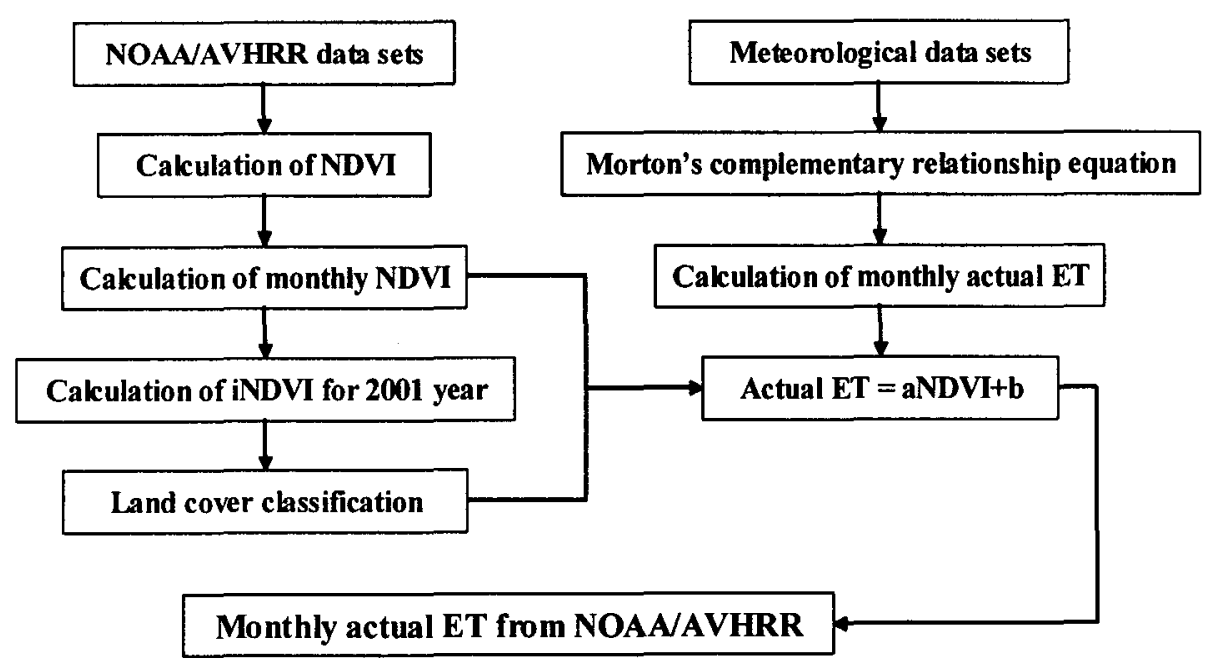

Fig. 1 Flowchart of this study 
heavy rains or severe weather, observations are made every hour or every 30 minutes. Daily meteorological data including four elements (temperatures, humidity, wind velocity, duration of sunshine) was used for calculating of monthly actual ETs.

Fig. 1 shows the flowchart of this study. There are two main procedures. One is to calculate
NDVI and to create land cover map from NOAAAVHRR data set. NDVI is normalized difference vegetation index. The other is calculation actual evapotranspiration from meteorological data set. Finally, relationship between NDVI and actual evapotranspiration was used to estimate actual evapotranspiration from NOAA-AVHRR data set.

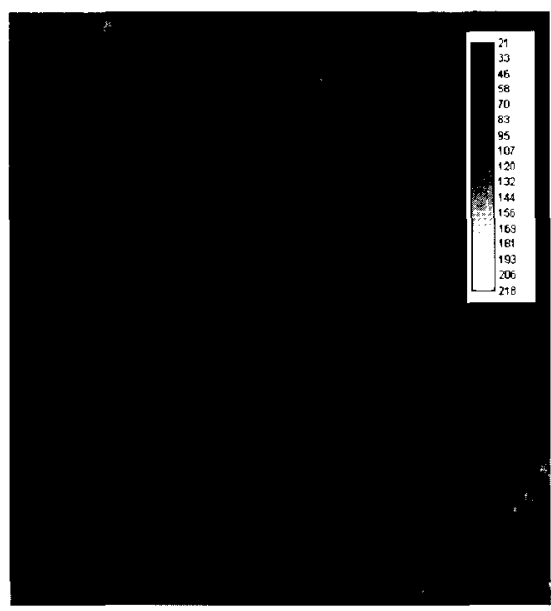

(a) raw image

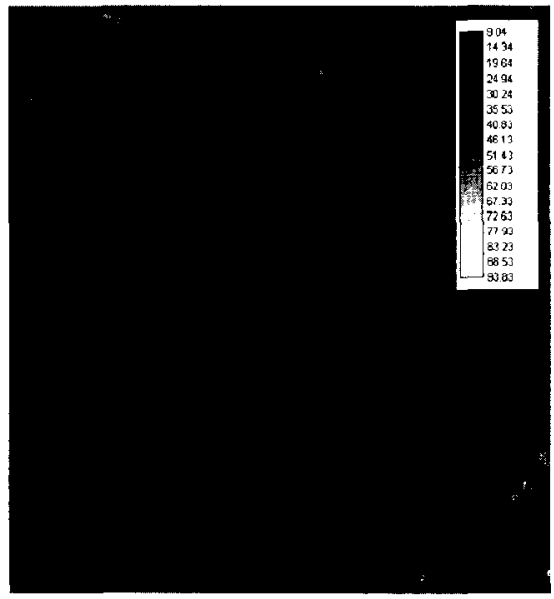

(c) Albedo image
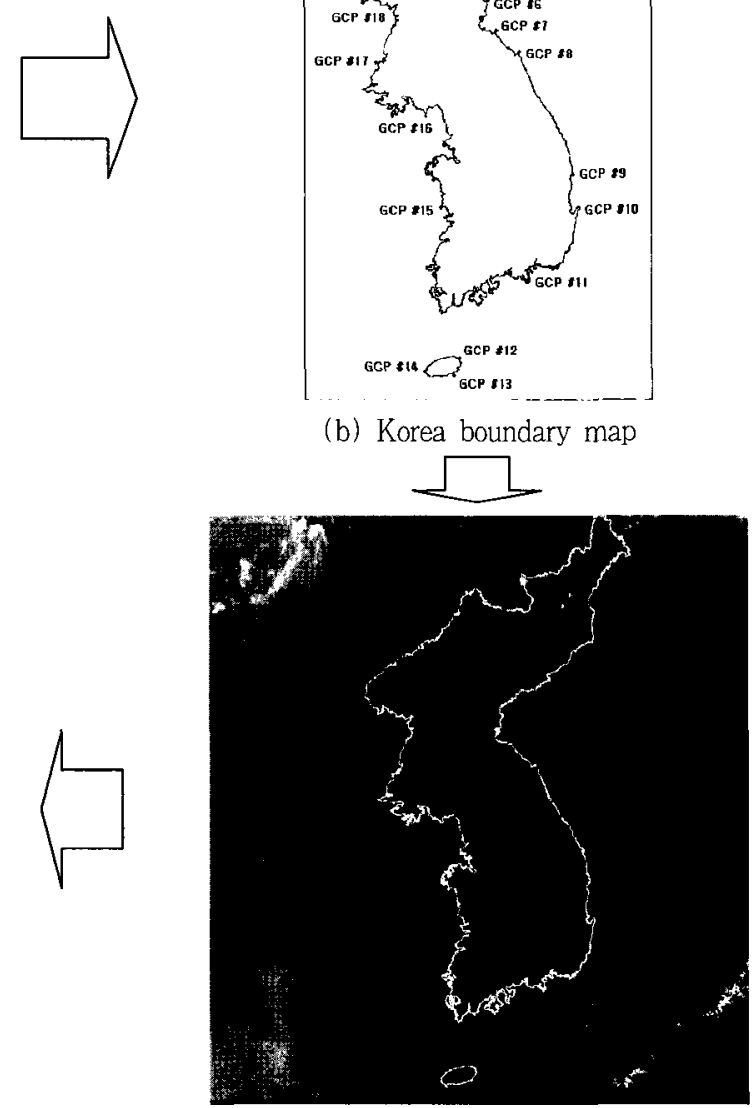

(b) Korea boundary map

(d) geo-corrected image

Fig. 2 Pre-processing 


\section{Pre-processing of NOAA-AVHRR Images}

Firstly, NOAA-AVHRR images are required to correct topographically because raw images have no coordinate system. Secondly, it is necessary to transfer the pixel values into albedo because pixels of raw images include just reflectance value of surface objects. NGIS digital maps have TM (Transverse Mercator) coordinate system, so raw images were corrected into same coordinate system using Korea boundary digital map with 19 GCPs. Fig. 2 shows pre-processing of NOAA-AVHRR images. Used resampling option was a nearest neighbor option in which the new grid value is the same as that in the nearest cell in the old grid.

\section{IN. NDVI and Land Cover Map}

NDVI developed for estimating the state of the vegetation (Rouse et al., 1974), has been widely adopted and applied due to its effectiveness as a surrogate measure of biophysical parameters. NDVI can be represented as follow for application of NOAA-AVHRR data.

$$
N D V I=\frac{C h .2-C h .1}{C h .2+C h .1}
$$

where Ch.1, 2 are the reflectance in the visible red (channel 1) and near infrared channel (channel 2) of NOAA-AVHRR, respectively. The NDVI of cloud covered area shows negative value because the value of $\mathrm{Ch} .1$ is greater than that of Ch. 2 in cloud covered area. The NDVI of non cloud covered area has positive value. The maximum value composite (MVC) image was produced to extract the maximum value of each pixel comparing the values among the series of NDVI images. Monthly NDVI was created by MVC method. This method is that pixel value of monthly NDVI revalued into maximum value of daily NDVI's pixel value from NOAA-AVHRR images for one month. Also, imageries in the winter period are not suitable for obtaining ground surface information due to snow cover. From five to fifteen scenes per month used to create monthly NDVI by this reason.

In this study, MVC values were calculated monthly from consecutive NDVI images with the exception of snowing season.

Also, iNDVI (integrated NDVI) can be used as representative NDVI within a given period of time (Fig. 3).

$$
i N D V I=\frac{\sum\left(N D V I_{j} \times d j\right)}{\sum d_{j}}
$$

where $\mathrm{NDVI}_{\mathrm{j}}$ is $\mathrm{j}^{\text {th }} \mathrm{NDVI}$ and $\mathrm{d}_{\mathrm{j}}$ is observed day of $\mathrm{NDVI}_{\mathrm{j}}$.

Land cover map was derived from iNDVI using histogram classification method (Fig. 3). This method may categorize vegetation area which takes similar ground characteristics into a land cover class. Land cover map can be used for estimating ET of each land cover classes.

\section{Actual ET from Meteorological Data}

Morton (1978) and Brutsaert et al. (1979) suggested that actual ET can be estimated by the complementary relationship and it was represented by:

$$
E a=2 \cdot E p-E p p \cdots \cdots \cdots \cdots \cdots \cdots \cdots \cdots \cdots \cdots \cdots \cdots \cdots \cdots(3)
$$


where Ea is actual ET (mm/day), Ep is potential ET by Priestly-Taylor's method (mm/day) and Epp is potential ET by Penman's method (mm/day).

$$
\begin{aligned}
& E p=1.26 \frac{\Delta}{\Delta+r}\left(R_{n}+M-G\right) \\
& E p p=\frac{\Delta}{(\Delta+r)}\left(R_{n}+M-G\right)+\frac{r}{\Delta+r} f(u)\left(e_{s}-e_{a}\right) \\
& \text {.................................................. (5) } \\
& E_{a}=\leq E p p \\
& M=0.66 L_{n}-0.44 R_{n} \\
& G=C_{r} \cdot R_{n}
\end{aligned}
$$

where $R_{n}$ is net radiation $\left(J / \mathrm{m}^{2} / \mathrm{d}\right), M$ is advection $\left(\mathrm{J} / \mathrm{m}^{2} / \mathrm{d}\right), \mathrm{G}$ is soil heat flux $\left(\mathrm{J} / \mathrm{m}^{2} / \mathrm{d}\right), \Delta$ is slope of saturation vapor pressure graph $\left(\mathrm{hPa} /{ }^{\circ} \mathrm{C}\right), r$ is constant of psychrometer $\left(\mathrm{hPa} /{ }^{\circ} \mathrm{C}\right), \mathrm{f}(\mathrm{u})$ is function of wind velocity $(\mathrm{mm} / \mathrm{hpa} / \mathrm{d})$, $e_{s}$ is saturation vapor pressure graph $(\mathrm{hPa}), \mathrm{e}_{\mathrm{a}}$ is actual saturation vapor pressure graph $(\mathrm{hPa}), \mathrm{L}_{\mathrm{n}}$ is long wave radiation $\left(\mathrm{j} / \mathrm{m}^{2} / \mathrm{d}\right), \mathrm{Cr}$ is soil heat flux coefficient. Some of all value are observation data and the others are calculated value by these follow equations.

$$
\begin{aligned}
& \Delta=\frac{1779.75 \times \ln 10 \times e_{s}}{(237.3+t)^{2}} \\
& r=\frac{1005 \times P_{r}}{0.622 \times \lambda}
\end{aligned}
$$

$$
\begin{aligned}
& f(u)=0.26(1+0.54 u) \\
& e_{s}=6.11 \times 10^{7.5} \times(237.3+t) \\
& P_{r}=1013.25-0.119861 H+5.356 \times 10^{-6} H^{2} \cdots(1
\end{aligned}
$$

$$
\lambda=(2501-2.37 t) \times 10^{3}
$$

where $\mathrm{t}$ is atmospheric temperature $\left({ }^{\circ} \mathrm{C}\right), \mathrm{Pr}$ is atmospheric pressure $(\mathrm{hPa}), \lambda$ is latent heat of evaporation $(\mathrm{J} / \mathrm{kg})$, $\mathrm{u}$ is wind velocity on $2 \mathrm{~m}$ from surface, $\mathrm{H}$ is altitude $(\mathrm{m})$.

Many empirical equations for estimating actual flux of solar radiation from duration of sunshine are linear equations which regard the ratio of duration of sunshine to possible duration of sunshine as parameter.

$$
\frac{I}{I_{o}}=(a+b) \frac{n}{N}
$$

Where $\mathrm{I}$ is flux of solar radiation, $\mathrm{I}_{0}$ is flux of solar radiation at the outer limit of the atmosphere, a and $\mathrm{b}$ are regional coefficients, $\mathrm{n}$ is duration of sunshine and $\mathrm{N}$ is possible duration of sunshine. Table 1 shows $a$ and $b$ of each large river basin from monthly flux of solar radiation.

Table 1 Regional coefficients for calculating flux of solar radiation

\begin{tabular}{lcc}
\hline \multicolumn{1}{c}{ Basin Name } & $\mathrm{a}$ & $\mathrm{b}$ \\
\hline Han River & 0.210 & 0.492 \\
Nak-dong River & 0.199 & 0.517 \\
Geum River & 0.182 & 0.561 \\
Yeong-san River & 0.178 & 0.587 \\
Seom-jin River & 0.190 & 0.528 \\
\hline
\end{tabular}

Net radiation was estimated using Penman method as follow.

$$
\begin{aligned}
R_{n}= & S_{n}-L_{n} \\
= & (1-\alpha) I-0.0864 \sigma(t+273)^{4}\left(0.56-0.092 \sqrt{e_{a}}\right) \\
& \left(0.1+0.9 \frac{n}{N}\right)
\end{aligned}
$$

where $S_{n}$ is short wave radiation $\left(\mathrm{J} / \mathrm{m}^{2} / \mathrm{d}\right), \alpha$ is 
Table 2 Monthly surface albedo

\begin{tabular}{lcccccccccccc}
\hline \multicolumn{1}{c}{ Class } & Jan & Feb & Mar & Apr & May & Jun & Jul & Aug & Sep & Oct & Nov & Dec \\
\hline Water & 0.01 & 0.09 & 0.08 & 0.07 & 0.06 & 0.06 & 0.06 & 0.06 & 0.07 & 0.08 & 0.10 & 0.11 \\
Urban & 0.32 & 0.32 & 0.30 & 0.30 & 0.28 & 0.27 & 0.28 & 0.30 & 0.30 & 0.30 & 0.30 & 0.32 \\
Evergreen & 0.09 & 0.10 & 0.10 & 0.10 & 0.11 & 0.12 & 0.12 & 0.12 & 0.12 & 0.11 & 0.11 & 0.10 \\
Deciduous & 0.10 & 0.10 & 0.10 & 0.10 & 0.13 & 0.15 & 0.15 & 0.15 & 0.15 & 0.14 & 0.13 & 0.10 \\
Paddy & 0.16 & 0.15 & 0.10 & 0.08 & 0.08 & 0.10 & 0.13 & 0.22 & 0.18 & 0.15 & 0.15 & 0.15 \\
\hline
\end{tabular}

Table 3 Monthly soil heat flux coefficient

\begin{tabular}{lcccccccccccc}
\hline \multicolumn{1}{c}{ Class } & Jan & Feb & Mar & Apr & May & Jun & Jul & Aug & Sep & Oct & Nov & Dec \\
\hline Water & 0.20 & 0.20 & 0.20 & 0.20 & 0.20 & 0.20 & 0.20 & 0.20 & 0.20 & 0.20 & 0.20 & 0.20 \\
Urban & 0.40 & 0.40 & 0.40 & 0.40 & 0.40 & 0.40 & 0.40 & 0.40 & 0.40 & 0.40 & 0.40 & 0.40 \\
Evergreen & 0.04 & 0.04 & 0.04 & 0.04 & 0.04 & 0.04 & 0.04 & 0.04 & 0.04 & 0.04 & 0.04 & 0.04 \\
Deciduous & 0.15 & 0.15 & 0.15 & 0.10 & 0.06 & 0.05 & 0.05 & 0.05 & 0.05 & 0.10 & 0.12 & 0.15 \\
Paddy & 0.15 & 0.15 & 0.12 & 0.15 & 0.15 & 0.08 & 0.08 & 0.08 & 0.08 & 0.10 & 0.15 & 0.15 \\
\hline
\end{tabular}

albedo and $\sigma$ is Stefan-Boltzmann constant $(0.57$ $\left.\times 10^{-8} \mathrm{~W} / \mathrm{m}^{2} / \mathrm{K}^{4}\right)$

Albedo $(\alpha)$ and soil heat flux coefficient $\left(\mathrm{C}_{\mathrm{r}}\right)$ are used empirical value (Table 2-3).

Since, daily meteorological data are necessary to use the complementary relationship, weather elements (e.g., temperature, humidity, wind velocity, duration of sunshine) are acquired from the 77 meteorological stations in Korea. Fig. 4 shows actual ETs for each basin.

In general, actual ET of Han River basin located at central part of the Korea peninsula less than that of others located at southern part (Table 4). However, actual ET of Seom-jin River basin located at southern part was similar to that of Han River basin, because mean temperature of two basins was similar in 2001. Total actual ET of five river basin is $822.7 \mathrm{~mm}$ from Jan. to Nov. of 2001.

\section{Estimation of Monthly ET Using NDVI from NOAA-AVHRR Data}

Satellite-derived NDVI is very useful tool for the frequent monitoring of green vegetation cover. The state of vegetation has a correlations with meteorological condition, and meteorological condition also has high correlation with ET. Therefore, it can be considered that ET at a forest region such as the Korean peninsula is linearly proportional to the NDVI.

The histogram of NDVI reflects seasonal changes of vegetation very well. Linear regression analysis was performed on each land cover. The results of this procedure may offer the method for estimating directly actual ET using NDVI at any point. Regression equations, $E a=a \cdot N D V I+b$ type, of each land cover class were derived from multiple regression analysis (Table 5). 


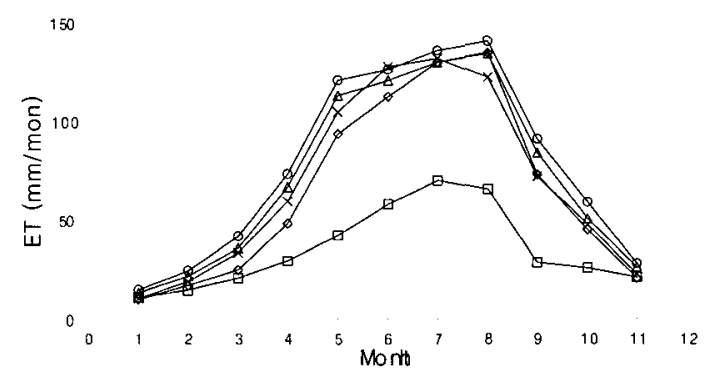

(a) Han River basin

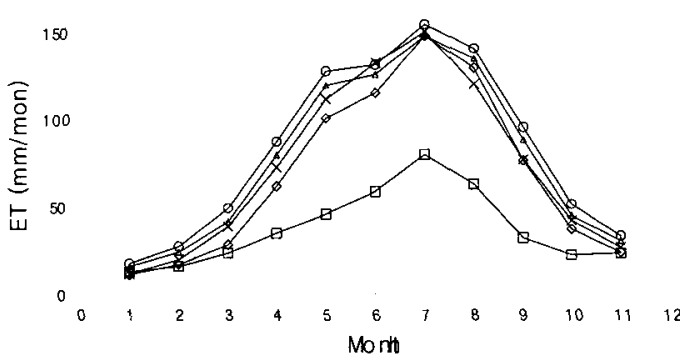

(c) Nak-dong River basin

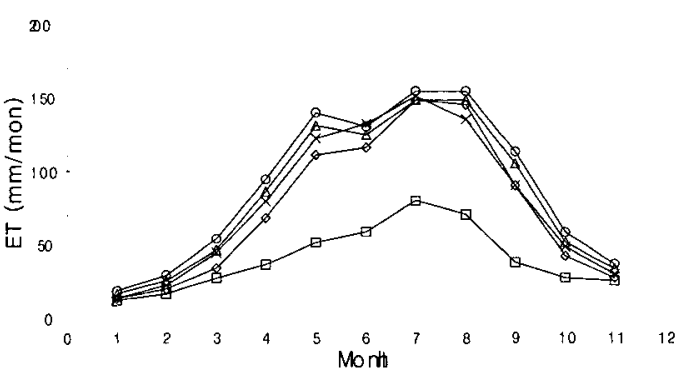

(b) Geum River basin

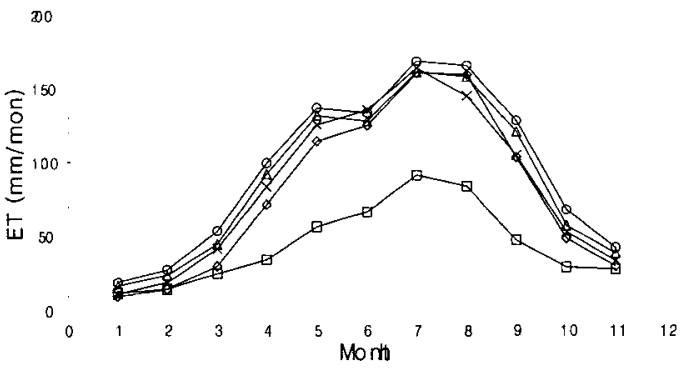

(d) Yeong-san River basin

so

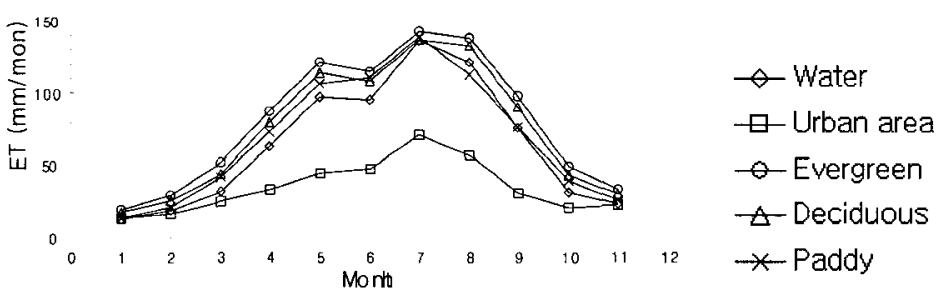

(e) Seom-jin River basin

Fig. 4 Estimated actual ET for each river basin (2001)

Table 4 Actual ETs of each river basin from Jan. to Nov, of 2001 year (mm)

\begin{tabular}{lcccccc}
\hline & Han & Geum & Nak-dong & Yeong-san & Seom-jin & Mean \\
\hline Water & 681.2 & 781.7 & 720.9 & 839.5 & 676.2 & 713.4 \\
Urban area & 361.1 & 414.5 & 383.5 & 459.9 & 353.6 & 379.0 \\
Paddy & 815.3 & 932.8 & 870.8 & 992.8 & 836.0 & 857.2 \\
Evergreen & 760.1 & 872.5 & 814.1 & 929.1 & 779.1 & 800.3 \\
Deciduous & 720.9 & 830.7 & 771.5 & 883.5 & 725.9 & 758.6 \\
\hline \multicolumn{1}{c}{ Total } & 732.6 & 842.1 & 783.7 & 896.8 & 743.1 & 770.8 \\
\hline
\end{tabular}


Table 5 Regression equations of each land cover class

\begin{tabular}{ccc}
\hline Land cover class & Regression equation & $\mathrm{R}^{2}$ \\
\hline Urban area & Eau $=441.86 \cdot \mathrm{NDVI}+4.8268$ & 0.46 \\
Paddy & Eap $=294.39 \cdot \mathrm{NDVI}+24.265$ & 0.41 \\
Deciduous & Ead $=413.42 \cdot \mathrm{NDVI}-13.268$ & 0.65 \\
Evergreen & Eae $=381.69 \cdot \mathrm{NDVI}-39.839$ & 0.62 \\
\hline
\end{tabular}

The actual ET can be estimated simply using these regression equations with only one parameter, NDVI, at any points. Fig. 5 shows actual ETs from NOAA-AVHRR images.

As a result, total actual ET of each basin was estimated from $696.8 \mathrm{~mm}$ to $959.3 \mathrm{~mm}$ in 2001 (Table 6). In fact, it is impossible to measure

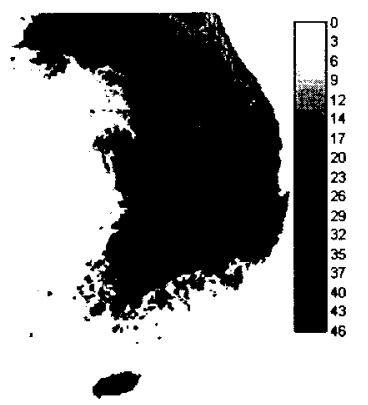

Mar.

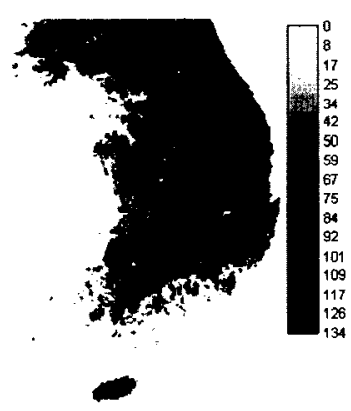

Jun.

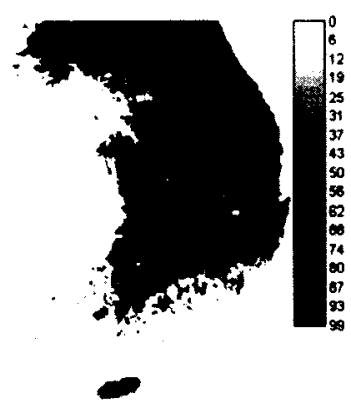

Sep.

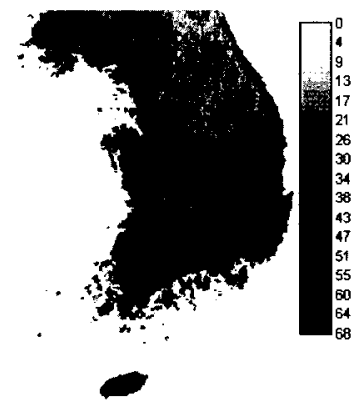

Apr.

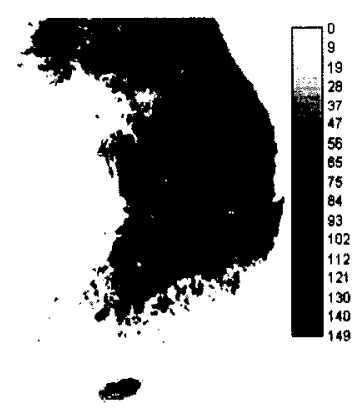

Jul.

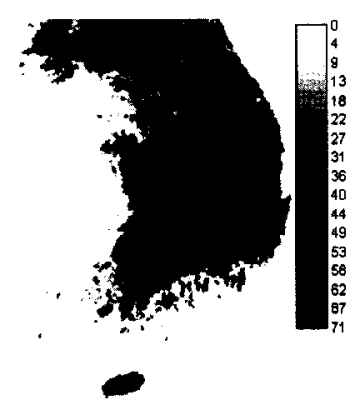

Oct.

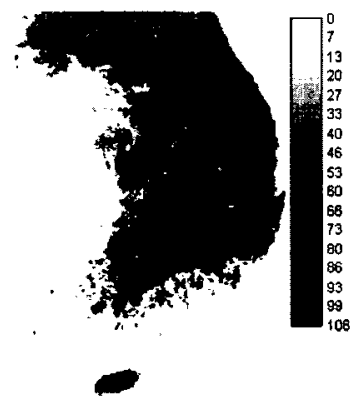

May

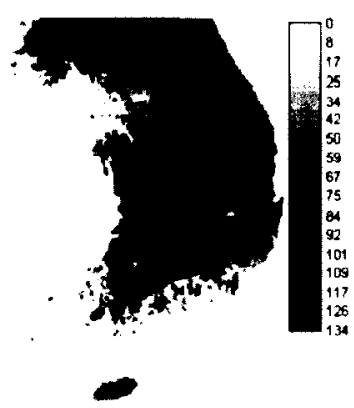

Aug.

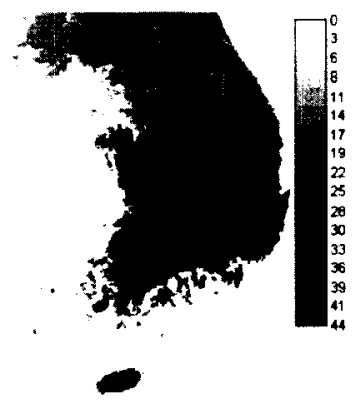

Nov.

Fig. 5 Monthly actual ET (mm/day) obtained by NDVI (2001) 
Kwon, Hyung Joong $\cdot$ Shin, Sha Chul $\cdot$ Kim, Seong Joon

Table 6 Comparison between rainfall and actual ET (mm)

\begin{tabular}{|c|c|c|c|c|c|c|c|c|c|c|c|c|c|c|c|}
\hline & \multicolumn{3}{|c|}{ Han } & \multicolumn{3}{|c|}{ Geum } & \multicolumn{3}{|c|}{ Nak-dong } & \multicolumn{3}{|c|}{ Yeong-san } & \multicolumn{3}{|c|}{ Seom-jin } \\
\hline & $\mathrm{R}$ & $\mathrm{Em}$ & En & $\mathrm{R}$ & $\mathrm{Em}$ & En & $\mathrm{R}$ & $\mathrm{Em}$ & En & $\mathrm{R}$ & Em & En & $\mathrm{R}$ & Em & En \\
\hline Mar & 17.6 & 31.3 & 30.5 & 16.6 & 45.8 & 45.0 & 9.9 & 40.6 & 45.9 & 19.8 & 43.9 & 45.1 & 23.3 & 43.7 & 45.2 \\
\hline Apr & 15.8 & 55.4 & 53.2 & 23.2 & 81.7 & 80.4 & 28.0 & 75.0 & 80.6 & 40.7 & 86.0 & 90.6 & 45.2 & 75.7 & 76.2 \\
\hline May & 18.4 & 94.7 & 95.4 & 23.0 & 124.3 & 125.3 & 44.4 & 113.8 & 115.4 & 29.4 & 125.6 & 132.5 & 56.6 & 108.3 & 109.3 \\
\hline Jun & 185.7 & 108.9 & 110.9 & 213.3 & 126.9 & 127.6 & 272.5 & 128.1 & 132.1 & 297.3 & 130.3 & 141.7 & 409.0 & 108.3 & 109.5 \\
\hline Jul & 395.1 & 119.4 & 134.2 & 233.8 & 147.5 & 150.2 & 186.1 & 148.3 & 160.9 & 178.5 & 160.9 & 183.2 & 291.5 & 136.1 & 140.2 \\
\hline Aug & 113.9 & 119.1 & 133.9 & 112.9 & 138.9 & 139.2 & 81.2 & 125.2 & 134.2 & 103.5 & 149.0 & 153.2 & 130.1 & 119.3 & 121.6 \\
\hline Sep & 91.6 & 69.4 & 70.9 & 40.9 & 95.3 & 94.8 & 132.1 & 80.8 & 87.5 & 57.7 & 109.8 & 114,9 & 99.4 & 81.9 & 84.2 \\
\hline Oct & 111.2 & 45.7 & 44.8 & 84.4 & 50.2 & 51.0 & 113.3 & 43.5 & 51.2 & 82.8 & 55.5 & 62.1 & 92.9 & 41.4 & 40.6 \\
\hline Nov & 17.0 & 23.8 & 23.0 & 13.1 & 31.5 & 32.6 & 10.3 & 28.5 & 30.6 & 19.7 & 35.7 & 36.0 & 15.4 & 28.3 & 29.5 \\
\hline Total & 966.3 & 667.7 & 696.8 & 761.2 & 842.1 & 846.1 & 877.8 & 783.8 & 838.4 & 829.4 & 896.7 & 959.3 & 1,163 & 743,0 & 756.3 \\
\hline
\end{tabular}

actual ET from field. Therefore, it is difficult to calibrate and verify actual ET using observed actual ET. For verification of actual ET from NOAA-AVHRR image, it is necessary to compare actual ET from NOAA-AVHRR image with actual ET by verified evapotranspiration equation. The result of comparison, RMSE was 0.41 (Table 6). For obtaining high accuracy, NDVI is required to be calibrated using more temporal series NOAA-AVHRR images.

\section{Conclusions}

This study is based on high correlation between NDVI from NOAA-AVHRR data and ET from meteorological data. Using this method, areal distribution data set of actual ET can be produced simply using NDVI calculated from NOAA-AVHRR data.

The following summaries were drawn:

1. NOAA-AVHRR images were corrected into
TM coordinate system using Korea boundary digital map with 19 GCPs and RMSE is 0.5 pixel.

2. Monthly NDVIs from Jan. to Nov. of 2001 year ware created by MVC method and land cover map was derived from iNDVI using histogram classification method with five classes.

3. Actual ET from meteorological data was estimated by Morton's complementary relationship equation and total actual ET of five river basin is $822.7 \mathrm{~mm}$ from Jan. to Nov. of 2001 year.

4. The regression equations of each land cover class were drived from linear regression analysis using high correlation between NDVI and actual ET.

5. Actual ET from NDVI was estimated by the regression equations and total actual ET of each basin is from $696.8 \mathrm{~mm}$ to $959.3 \mathrm{~mm}$.

This method is applicable to other countries on suitable calibration of relationships between NDVI and ET. This method makes it possible to estimate ET of any areas where enough meteo- 
rological and hydrological data are not available.

\section{Acknowledgements}

This study is a part of Water Management Information Project of Korea Agricultural \& Rural Infrastructure Corporation, and NOAA-AVHRR data was provided by Korea Meteorological Administration.

\section{References}

1. Chow, V. T., 1984, Handbook of applied hydrology, McGRAW-HILL Inc..

2. Morton, F. I., 1978, Estimating evapotranspiration from potential evaporation - practicality of an iconoclastic approach, $\mathrm{J}$, of Hydrol., Vol $38: 1-32$.

3. Brutsaert, W. and H. Stricker, 1979, An advection-aridity approach to estimate actual regional evapotranspiration, Water Resour. Res., Vol $15: 443-450$.

4. Rouse, J. W., R. H. Haas, J. A. Schell and D. W. Deering, 1974, Monitoring vegetation system in the great plains with ERTS, Proceedings, Third Earth Resources Technology Satellite-1 symposium, Greenbelt, NASA SP-351, 3010-317.

5. Running, S. W. and R. R. Nemani, 1988, Relating seasonal patterns of the AVHRR vegetation index to simulated photosynthesis and transpiration of forests in different climates, Remote Sensing Environ., Vol 24 : 347-367.

6. Tada, T., S. Kazama and M. Sawamoto, 1994, Estimation of evaportranspiration distribution by using NDVI, J. of Hydraulic Eng., Vol 38 : 155-160. 